ББК 63.4

$$
\begin{gathered}
\text { Организация конференции и издание материалов проведены } \\
\text { при финансовой поддержке Российского фонда фундаментальных исследований, } \\
\text { проект № 19-09-20008 }
\end{gathered}
$$

Утверждено к печати Ученым советом ИИМК РАН

Редакционная коллегия тома II: А. В. Поляков, Е. С. Ткач (отв. редакторы), М. Т. Кашуба, Л. Б. Кирчо, Е. А. Черлёнок, В. Я. Стёганцева, А. И. Климушина

Рещензенты: д. и. н. Л. Б. Вишняцкий, д. и. н. А. А. Выборнов

Программный комитет конференции: академик РАН, д. и. н., проф. М. Б. Пиотровский (Государственный Эрмитаж, почетный председатель); д. и. н. В. А. Лапшин (ИИМК РАН, председатель); д. и. н. А. В. Головнёв (МАЭ РАН, сопредседатель); д. и. н. В. А. Дергачёв (Высшая антропологическая школа, Молдова, сопредседатель); д. и. н. И. Ф. Попова (ИВР РАН, сопредседатель); академик АН Республики Узбекистан, д. и. н., проф. Э. В. Ртвеладзе (сопредседатель); к. и. н. А. В. Поляков (ИИМК РАН, зам. председателя); к. и. н. В. А. Алёкшин (ИИМК РАН, зам. председателя); д. и. н. Ю. Е. Берёзкин (МАЭ РАН); Dr., Prof. Н. Бороффка

(Германский археологический институт, Германия); В. С. Бочкарёв (ИИМК РАН);

Dr. Э. Кайзер (Свободный университет Берлина, Германия); к. и. н. М. Т. Кашуба (ИИМК РАН); д. и. н. Л. Б. Кирчо (ИИМК РАН); к. и. н. А. В. Кияшко (Южный федеральный университет); к. и. н. П. Ф. Кузнецов (СГСПУ); к. и. н. Н. М. Малов (СНИГУ); к. и. н. В. П. Никоноров (ИИМК РАН); Ю. Ю. Пиотровский (Государственный Эрмитаж); д. и. н., проф. Д. Г. Савинов (Институт истории СПбГУ); к. и. н. В. Н. Седых (Институт истории СПбГУ); к. и. н. Н. Н. Скакун (ИИМК РАН); к. и. н. Н. Ф. Соловьёва (ИИМК РАН); к. и. н. А. И. Торгоев (Государственный Эрмитаж); к. и. н. Е. А. Черлёнок (Институт истории СПбГУ)

Организационный комитет конференции: к. и. н. А. В. Поляков (ИИМК РАН, председатель); к. и. н. В. А. Алёкшин (ИИМК РАН, зам. председателя); В. С. Бочкарёв (ИИМК РАН); к. и. н. М. Т. Кашуба (ИИМК РАН); д. и. н. Л. Б. Кирчо (ИИМК РАН);

А. И. Климушина (ИИМК РАН, отв. секретарь); к. и. н. В. П. Никоноров (ИИМК РАН); Ю. Ю. Пиотровский (Государственный Эрмитаж); В. Я. Стеганцева (ИИМК РАН); В. В. Терёхина (ИИМК РАН, МАЭ РАН, отв. секретарь); к. и. н. Е. С. Ткач (ИИМК РАН); И. Ж. Тутаева (Государственный Эрмитаж); к. и. н. Е. А. Черлёнок (Институт истории СПбГУ)

Древности Восточной Европы, Центральной Азии и Южной Сибири в контексте связей и взаимодействий в евразийском культурном пространстве (новые данные и концепции): Материалы Международной конференции, 18-22 ноября 2019 г., Санкт-Петербург. Т. ІІ. Связи, контакты и взаимодействия древних культур Северной Евразии и цивилизаций Востока в эпоху палеометалла (IV-I тыс. до н. э.). К 80-летию со дня рождения выдающегося археолога В. С. Бочкарёва. - СПб.: ИИМК РАН, Невская Типография, 2019. - 287 с.

ISBN 978-5-907053-35-9

DOI 10.31600/978-5-907053-35-9 
Зайков В. В., Юминов А. М., Анкушев М. А., Носкевич В. В., Ткачёв В. В., Епимахов А. В. 2013. Горно-металлургические центры бронзового века в Зауралье и Мугоджарах // Известия Иркутского ГУ. № 1 (2). С. 174-195.

Ткачёв В. В. 2010. Горное дело и металлургия меди в Уральско-Мугоджарском регионе в позднем бронзовом веке // Известия Самарского НЦ РАН. 2010. Т. 12 (34), № 2. С. 268-271.

Ткачёв В. В. 2011. Уральско-Мугоджарский горно-металлургический центр эпохи поздней бронзы // РА. № 2. С. 43-55.

Ткачёв В. В. 2012. К вопросу о памятниках кожумбердынского типа эпохи бронзы Уральско-Мугоджарского региона // РА. № 1. С. 155-159.

Черных Е. Н. 1970. Древнейшая металлургия Урала и Поволжья. М.

\title{
METAL OBJECTS FROM SITES OF THE ALAKUL CULTURE OF THE SOUTHERN TRANS-URALS AND MUGODZHARS
}

\author{
Aleksandr V. Fomichev \\ Orsk Humanitarian-Technological Institute (branch) of the Orenburg State Pedagogical University, \\ Orsk, Russia
}

Keywords: Late Bronze Age, Alakul culture, metallurgy, metal objects.

In the Late Bronze Age, two mining and metallurgical centers functioned in the Southern TransUrals and Mugodzhars basing on the local copper deposits. Both of the two centers were related with local variants of the Alakul culture. Metallurgists of the Alakul culture produced various metal articles: weapons, working tools and ornaments. The variety of the metal objects corresponded to the general standards of the Eurasian Metallurgical Province. At the same time, peculiarities of the metal objects depending on the region of their production also are noticeable. In the Southern Trans-Ural region there are types of products characteristic of the West-Alakul variant and in the Mugodzhars, those typical of the Kozhum-Berdy variant of the Alakul culture are found.

\section{ОСОБЕННОСТИ СРУБНО-АНДРОНОВСКОГО ВЗАИМОДЕЙСТВИЯ НА ТЕРРИТОРИИ ОРЕНБУРГСКОГО ПРЕДУРАЛЬЯ В НАЧАЛЕ ПОЗДНЕГО БРОНЗОВОГО ВЕКА}

\author{
И. А. Файзуллин \\ Оренбургский государственньй педагогический университет, Оренбург, Россия
}

DOI: 10.31600/978-5-907053-35-9-249-251

Ключевые слова: срубная культура, алакульская культура, бытовые памятники, керамика, хронология.

Начало позднего бронзового века представлено на территории Оренбургского Предуралья двумя группами керамики: раннесрубной (Малоюлдашевское, Ивановское, II Сухореченское поселения) и раннеалакульской (Родниковское, II Кузьминковское поселения). Помимо этого, на Покровском поселении при помощи технико-технологического анализа выделена смешанная керамика двух этих культурных групп.

Наличие смешения двух представленных культурных групп напрямую указывает на их единую хронологическую позицию. Синхронность раннесрубнного и раннеалакульского материала отмечена в целом ряде научных работ (Потёмкина 1995: 23; Молодин и др. 2014: 142-144). Не касаясь вопроса происхождения алакульской культуры, отметим, что по мнению В. В. Ткачёва, на территории Приуралья раннеалакульское население претерпело влияние раннесрубного еще на самом начальном этапе культурогенеза. Кроме того, А. В. Епимаховым 
по зауральским материалам отмечено, что петровские (раннеалакульские) и раннесрубные памятники имеют ряд черт сходства и в некоторых случаях представлены синкретическими комплексами. Более того, проведенное им суммирование радиоуглеродных дат дает период 1880-1740 гг. до н. э. (1920-1690 гг. до н. э.), то есть хронологический интервал, следующий после синташтинских комплексов. Среди погребальных памятников Оренбургского Приуралья нужно отметить Боголюбовский курганный могильник, в материалах которого представлена керамика как раннесрубного (вдавление полой кости, расчесы, ногтевые вдавления и т. д.), так и раннеалакульского (утолщенный венчик, аккуратность лепки и т. д.) облика (Моргунова и др. 2014: 80-102).

Технико-технологический анализ, проведенный В. И. Мухаметдиновым, показал стабильное применение илистых глин в составе керамики. Такие сосуды довольно уверенно относятся к раннему периоду срубной культуры. Об этом свидетельствуют материалы курганных могильников Лабазы и Скворцовка. Керамика этих памятников была изготовлена из илистых глин. Кроме того, по материалам погребений этих могильников были получены радиоуглеродные даты, которые указывают на сооружение комплексов в XVIII-XVII вв. до н. э. Сосуд, изготовленный из ила, обнаружен также во II курганном могильнике у сел. Плешаново (Мухаметдинов 2012a), который находится в непосредственной близости от Малоюлдашевского поселения. По образцу дерева одного из перекрытий этого некрополя получена радиоуглеродная дата (3390 \pm 30 ВР; 1760-1610 ВС (95,4 \%)). Обнаружение сосудов из ила и илистых глин в раннесрубных могильниках подтверждает раннюю датировку Малоюлдашевской керамической коллекции.

Материалы представленных поселений позволяют коснуться вопроса о расселении представителей срубной и алакульских культур на раннем этапе их развития. Было отмечено, что население Родниковского поселения на начальном этапе эпохи поздней бронзы было раннеалакульским. Это подтверждается керамической коллекцией, которая как визуально, так и технологически тяготеет именно к алакульской традиции изготовления керамики (Мухаметдинов 2012б: 101-104). Ближайшие памятники, расположенные в бассейне среднего течения р. Урал, также содержали керамику этого типа (Купцова, Файзуллин 2012: 246-247). К памятникам с раннеалакульской керамикой относятся Покровское, II Кузьминковское и Краснохолмское поселения. Для курганных могильников Новая Белогорка и Герасимовка III наряду с раннесрубной характерно также достаточно большое количество раннеалакульской керамики.

Иная картина наблюдается северо-западнее. Памятники бассейна р. Самары содержат керамику раннего этапа срубной культуры. Так, Малоюлдашевское поселение на начальном этапе поздней бронзы было заселено раннесрубными племенами. Подобная картина характерна и для Токского, Ивановского и Сорочинского поселений, а также курганных могильников Скворцовка, Лабазы, Пролетарка и Александровка. Все эти памятники содержат керамику, характерную в большей или меньшей степени для раннесрубной эпохи (Файзуллин 2017).

В дальнейшем представители срубной культуры более активно, чем в ранний период, проникают в зону алакульского влияния, в том числе в бассейн Уральского правобережья, и активно взаимодействуют с местным населением. Эти ситуация хорошо прослежена в строительных и гончарных традициях Родниковского поселения срубно-алакульского периода. При сохранении в основном алакульских приемов домостроительства, в гончарстве начинают преобладать навыки изготовления посуды, характерные для срубной культуры.

В то же время наблюдается и обратный процесс, когда в керамических коллекциях памятников бассейна р. Самары начинает появляться алакульская керамика развитого этапа. 
При этом в рассматриваемых случаях влияние алакульской традиции на срубную не столь ощутимо, как в случае с влиянием срубной традиции на алакульскую. Так, на Малоюлдашевском поселении срубно-алакульская посуда составляет лишь 15,5 \%, а срубная - более $50 \%$ от общего числа керамики.

Таким образом, можно отметить, что взаимодействие срубного и алакульского населения на раннем этапе происходило на территории Западного Оренбуржья не повсеместно. Об этом свидетельствует наличие чистых комплексов раннесрубной керамики в бассейне р. Самары и чистых раннеалакульских комплексов в бассейне р. Урал. Дальнейшее изучение рассматриваемого региона позволит уточнить данные о процессе расселения древних племен на начальном этапе эпохи поздней бронзы.

\section{Литература}

Купцова Л. В., Файзуллин И. А. 2012. Родниковое поселение - поликультурный памятник эпохи бронзы с территории Оренбуржья // Проблеми дослідження пам'яток археологіi Східноі Украіни. Луганьск. С. 246-252.

Молодин В. И., Епимахов А. В., Марченко Ж. В. 2014. Радиоуглеродная хронология культур эпохи бронзы Урала и юга Западной Сибири: принципы и подходы, достижения и проблемы // Вестник НГУ. Т. 13, вып. 3. С. 136-167.

Моргунова Н. Л., Гольева А. А., Евгеньев А. А., Крюкова Е. А., Купцова Л. В., Рослякова Н. В., Салугина Н. П., Турецкий М. А., Хохлов А. А., Хохлова О. С. 2014. Боголюбовский курганный могильник срубной культуры в Оренбургской области. Оренбург.

Мухаметдинов В. И. 2012а. Технико-технологический анализ керамики Плешановского II курганного могильника // АПО. Вып. 10. С. 134-140.

Мухаметдинов В. И. 2012б. Технико-технологический анализ керамики Родникового поселения эпохи бронзы // Там же. С. 101-112.

Потемкина Т. М. 1995. Проблемы связей и смены культур населения Зауралья в эпоху бронзы // РА. № 1. С. 14-27.

Файзуллин И. А. 2017. Хронологическая позиция бытовых памятников позднего бронзового века с территории Оренбургского Предуралья // Деревянко А. П., Тишкин А. А. (отв. ред.). V (XXI) ВАС (Электронный ресурс): Сб. науч. тр. Барнаул. С. 1062-1063.

\section{PECULIARITIES OF THE SRUBNAYA-ANDRONOVO INTERACTION THROUGHOUT THE ORENBURG CIS-URAL REGION IN THE BEGINNING OF THE LATE BRONZE AGE}

\section{Ildar A. Fayzullin}

Orenburg State Pedagogical University, Orenburg, Russia

Keywords: Timber-Grave (Srubnaya) culture, Alakul culture, household monuments, ceramics, chronology.

This paper analyses settling complexes of the Late Bronze Age in the Orenburg Cis-Urals. Pottery from the settlements was compared with that from burial complexes. Besides, the wide application of technical and technological analysis has shown certain regularities in the aspects of cultural interactions between the Srubnaya (Timber-Grave) and Alakul cultures.

Pottery, as a major cultural and chronological indicator, allows us to determine fairly precisely the boundaries of distribution of particular archaeological cultures. Materials from settlements under consideration make it possible to touch the problem of settlement of representatives of the Srubnaya and Alakul cultures at the early stage of their development. 